\title{
FAKTOR KELELAHAN PERAWAT RAWAT INAP RUMAH SAKIT
}

\author{
Faizal Miftah N., \& Rojali \\ Dosen Jurusaan Kesling Poltekkes Kemenkes Jakarta II \\ Email: rojalijaya@yahoo.com
}

\begin{abstract}
Abstrak
Rumah Sakit Harum Sisma Medika merupakan perusahaan di bawah pengelolaan PT. Sismadi Mancorpindo, yaitu perusahaan yang bergerak dalam bidang pelayanan kesehatan antara lain rumah sakit, klinik, apotik, pendidikan paramedik, konsultan namajemen rumah sakit dan bidang kesehatan lainnya. Rumah Sakit Harum Sisma Medika tergabung dalam Ikatan Rumah Sakit Jakarta Metropolitan dan Persatuan Rumah Sakit Seluruh Indonesia (PERSI no. Reg. 10 A.130070), serta memenuhi standar Akreditasi Kementrian Kesehatan Republik Indonesia. Hasil penelitian didapatkan sebanyak $29(61,7 \%)$ perawat rawat inap Rumah Sakit Harum Sisma Medika mengalami tingkat kelelahan sedang. Dari hasil penelitian terkait dengan faktor internal diperoleh bahwa sebagian besar; berusia 20-30 tahun, berjenis kelamin perempuan, sudah bekerja $>5$ tahun. Waktu tidur dimalam hari $>8$ jam. Hasil uji statistik chisquare yang didapatkan bahwa faktor eksternal (durasi kerja, shif kerja) dan faktor internal (usia, jenis kelamin, masa kerja, waktu tidur) tidak ada hubungan yang signifikan dengan tingkat kelelahan. Sedangkan faktor yang memiliki hubungan dengan tingkat kelelahan hanya dari foktor eksternal (waktu istirahat).
\end{abstract}

Kata Kunci: Perawat, kelelahan, waktu istirahat dan pelayanan kesehatan

\section{Abstract}

Harum Sisma Medika Hospital is a company under the management of PT. Sismadi Mancorpindo, which is a company engaged in the field of health services such as hospitals, clinics, pharmacies, education paramedics consultant namajemen hospital and other health fields. Harum Sisma Medika Hospital is also incorporated in the Jakarta Metropolitan Hospital Association and Association of Indonesian Hospitals (PERSI Reg.10 A.130070), and meets the Accreditation standards of the Ministry of Health of the Republic of Indonesia. The results of this study were $29(61,7 \%)$ in the hospitalization of Harum Sisma Medika Hospital experienced moderate fatigue level From the research result related to internal factors, it is found that most of them: Aged 20-30 years, female sex, have been working $>5$ years. Sleep time at night $>8$ hours from the result of chi square statistic test, it is found that external factor (duration of work, work shifting) and internal factor (age, sex, work period, bedtime) studied are not significantly related with fatigue levels and factors that are related to fatigue levels only from external faktor (rest time).

Keywords: Nurses, fatigue, rest time and health services

\section{PENDAHULUAN}

Tenaga kesehatan adalah setiap orang yang mengabdikan diri dalam bidang kesehatan serta memiliki pengetahuan dan/ atau ketrampilan melalui pendidikan di bidang kesehatan yang untuk jenis tertentu memerlukan kewenangan untuk melakukan upaya kesehatan. Menurut Daniel L (2006) dalam Ritonggsari

a (2016) keterampilan perawat klinik meliputi beberapa tahap, tahap pemula atau belum berpengalaman, tahap II pemula lanjut memiliki beberapa pengalaman dalam pekerjaan, tahap III sangat kompeten berada direntang pekerjaan 2-3 tahun, tahap IV sudah mahir dalam praktik keperawatan, dan tahap $V$ ahli memiliki pemahaman dan pengalaman yang tinggi.

Penelitian National Institute for Occupational Safety and Healt (NOISH) dalam Ritongga (2016) yaitu Lembaga Nasional untuk Keselamatan dan Kesehatan Kerja adalah perawat. Data World Health 
Organization tahun (2009) dalam Ritongga (2016) menyatakan bahwa terdapat 7,8 juta perawat di 198 negara. Badan PPSDM Kesehatan Kementerian Kesehatan RI (2015) melaporkan jumlah rumah sakit pada tahun 2014 sebanyak 2.406 dengan jumlah tenaga kesehatan terbanyak pada posisi perawat yaitu 122.689 orang yang bertugas di rumah sakit. Perawat merupakan tenaga medis yang memiliki kontak langsung dengan paling sering dengan pasien sehingga rentan terhadap kelelahan. Kelelahan merupakan ancaman besar terhadap keselamatan pasien. The Join Comission pada tahun 2008 melaporkan $300 \%$ lebih perawat membuat kesalahan karena kelelahan dan berujung kepada kematian paasien. Sebuah studi dari perawat menunjukkan risiko seorang perawat membuat kesalahan meningkat secara signifikan ketika shift perawat melebihi 12 jam, ketika lembur atau ketika jam kerja lebih dari 40 jam perminggu.

Menurut Kleiber dan Ensman (Novita, 2012 dalam Ritongga, 2016), publikasi mengenai tentang kelelahan pekerja di eropa menunjukkan tenaga kesehatan, khususnya perawat menempati peringkat pertama pekerjaan yang mudah mengalami kelelahan kerja $(43 \%)$ dibandingkan dokter dan apoteker. Menurut Ritongga (2016), persentase beban tugas perawat yang tinggi dapat mengakibatkan penurunan produktivitas dan memacu stres. Stres yang berkepanjangan dapat mengakibatkan kelelahan fisik, mental dan emosional yang dapat berujung terjadinya kelelahan kerja pada perawat.

Rumah Sakit Harum Sisma Medika Jakarta Timur sebagai instansi yang bergerak di bidang pelayanan kesehatan beroperasi 24 jam setiap harinya, memiliki 4 ruang rawat inap, memiliki 3 shift jam kerja dengan 94 tempat tidur dan 47 perawat. Rumusan masalah penelitian ini adalah bagaimana faktor-faktor yang mempengaruhi tingkat kelelahan pada perawat bagian rawat inap di Rumah Sakit Harum Siswa Medika.

\section{METODE PENELITIAN}

Penelitian dilakukan di Rumah Sakit Harum Sisma Medika Jakarta Timur pada bulan Mei 2017. Desain penelitian cross sectional dengan populasi adalah perawat rawat inap tahun 2017 sebanyak 47 orang. Sampel yang diambil adalah sampel populasi yang memenuhi kriteria. Kriteria inklusi adalah perawat bagian Rawat Inap Rumah Sakit Harum Sisma Medika, bersedia menjadi responden penelitian, dan hadir saat penelitian berlangsung. Data primer diperoleh dari wawancara dengan perawat bagian Rawat Inap menggunakan instrument Industrial Fatique Research Committe/IFRC dari Jepang.

Variabel penelitian terdiri dari kelelahan perawat, durasi kerja, istirahat, shift kerja, usia, jenis kelamin, masa kerja dan waktu tidur. Hasil penelitian dikagorikan kelelahan rendah bila 30-52, kelelahan sedang bila 53-57 dan kelelahan sangat tinggi bila 99-120. Analisis statisik yang dilakukan adalah analisis deskriptif untuk univariat, dan uji chi-square untuk mengetahui hubungan variabel.

\section{HASIL DAN PEMBAHASAN}

Hasil penelitian terhadap perawat pada faktor durasi kerja dapat diketahui bahwa durasi kerja perawat kurun dari 8 jam berjumlah 32 perawat $(68,1 \%)$ dan lebih dari 8 jam berjumlah 15 perawat $(31,9 \%)$ dapat dilihat pada tabel 1.

Tabel 1. Distribusi Perawat Berdasarkan Durasi Kerja

\begin{tabular}{ccc}
\hline Durasi Kerja & Jumlah & Persentasi \\
\hline > 8 jam & 15 & 31.9 \\
\hline$\leq 8$ Jam & 32 & 68.1 \\
\hline Total & 47 & 100 \\
\hline
\end{tabular}

Durasi kerja perawat yang paling banyak $\leq 8$ jam dikarenakan pasien yang berada di bagian rawat inap tidak terlalu banyak sehingga perawat tidak mempunyai beban pekerjaan yang terlalu banyak.

Distribusi perawat terhadap waktu istirahat dengan kriteria cukup berjumlah 32 
perawat $(68,1 \%)$, kiriteria kurang berjumlah 15 perawat $(31,9 \%)$ dapat dilihat pada tabel 2. Waktu istirahat perawat hampir sebagian besar cukup dikarenakan dari pasien di bagian rawat inal terlalu banyak maka perawat dapat beristirahat dengan cukup, sehingga perawat dapat kembali fokus pada pekerjaannya.

Tabel 2. Distribusi Perawat Berdasarkan Waktu Istirahat

\begin{tabular}{ccc}
\hline Waktu Istirahat & Jumlah & Persentasi \\
\hline Kurang & 15 & 31.9 \\
\hline Cukup & 32 & 68.1 \\
\hline Total & 47 & 100 \\
\hline
\end{tabular}

Sebagian besar jumlah perawat pada shift kerja sore sebanyak 18 perawat $(38,3 \%)$, shift pagi berjumlah 16 perawat $(34,0 \%)$, dan shift malam berjumlah 13 perawat $(27,7 \%)$ dapat dilihat pada tabel 3 . Shift kerja terdapat 3 shift kerja pada perawat di bagian rawat inap dan jumlah perawat yang terbanyak pada shift sore, dikarenakan sebagian besar perawat yang diwawancara pada shift sore.

Tabel 3. Distribusi Perawat Berdasarkan Shift Kerja

\begin{tabular}{ccc}
\hline Shift Kerja & Jumlah & Persentasi \\
\hline Shift Pagi & 16 & 34.0 \\
\hline Shift Sore & 18 & 38.3 \\
\hline Shift Malam & 13 & 27,7 \\
\hline Total & 47 & 100 \\
\hline
\end{tabular}

Distribusi perawat berdasarkan usia dengan kategori 20-30 tahun berjumlah 31 perawat $(66,0 \%)$, lebih dari 30 tahun berjumlah 16 perawat $(34,0 \%)$ dapat dilihat pada tabel 4 . Hasil termuda yaitu 20 tahun dan usia tertua 50 tahun. Data yang didapat terbanyak usia perawat kisaran 20-30 tahun. Menurut Wignosoebroto (2008) dalam Kusumawardani (2012) kepastian energi yang mampu dihasilkan oleh seseorang juga akan dipengaruhi oleh faktor usia. Kapasitas maksimum seorang pekerja adalah pada usia $20-30$ tahun yaitu $100 \%$.
Tabel 4. Distribusi Perawat Berdasarkan Usia

\begin{tabular}{ccc}
\hline Usia & Jumlah & Persentasi \\
\hline 20-30 tahun & 31 & 66.0 \\
\hline$>30$ tahun & 16 & 34.0 \\
\hline Total & 47 & 100 \\
\hline
\end{tabular}

Masa kerja perawat yang kuarang dari 5 tahun berjumlah 17 perawat $(36,2 \%)$ dan yang lebih dari 5 tahun berjumlah 30 perawat $(63,8 \%)$ dapat dilihat pada tabel 5 . Masa kerja perawat di bagian Rawat Inap sebagian besar sudah berpengalaman dikarenakan banyak yang sudah bekerja lebih dari 5 tahun, sehingga pengalaman kerjanya lebih banyak.

Tabel 5. Distribusi Perawat Berdasarkan Masa Kerja

\begin{tabular}{ccc}
\hline Usia & Jumlah & Persentasi \\
\hline$<5$ tahun & 17 & 36.2 \\
\hline$>5$ tahun & 30 & 63.8 \\
\hline Total & $\mathbf{4 7}$ & $\mathbf{1 0 0}$ \\
\hline
\end{tabular}

Berdasarakan waktu tidur $\leq 8$ jam berjumlah 3 perawat $(6,4 \%)$ dan yang $>8$ jam berjumlah 44 perawat $(93,6 \%)$ dapat dilihat pada tabel 6 . Waktu tidur perawat didapatkan bahwa sebagian besar perawat memiliki waktu tidur $>8$ jam.

Tabel 6. Distribusi Perawat Berdasarkan Masa Kerja

\begin{tabular}{ccc}
\hline Waktu Tidur & Jumlah & Persentasi \\
\hline < 8 Jam & 3 & 6,4 \\
\hline < 8 Jam & 44 & 93.6 \\
\hline Total & 47 & 100 \\
\hline
\end{tabular}

Hal ini menunjukkan bahwa perawat memiliki waktu tidur yang cukup, sehingga perawat tidak merasa cepat lelah dalam bekerja.

Distribusi perawat yang mengalami kelelahan rendah berjumlah 29 perawat $(61,7 \%)$, kelelahan sedang berjumlah 18 
perawat $(38,3 \%)$ dapat dilihat pada tabel 7 . Tingkat kelelahan perawat di Rawat Inap Rumah Sakit Harum Sisma Medika Jakarta Timur Tahun 2017 mengalami kelelahan rendah berjumlah 29 perawat dengan persentase 61,7 . Hal ini menunjukkan bahwa perawat kelelahan sedang lebih banyak dibandingkan dengan kelelahan sedang, sehingga masih dalam kelelahan yang wajar.

Tabel 7. Distribusi Perawat Berdasarkan Tingkat Kelelahan

\begin{tabular}{ccc}
\hline Tingkat Kelelahan & Jumlah & Persentasi \\
\hline Rendah (30-52) & 29 & 6174 \\
\hline Sedang (53-75) & 18 & 38.3 \\
\hline Total & $\mathbf{4 7}$ & $\mathbf{1 0 0}$ \\
\hline
\end{tabular}

Pada table 8 , dari 47 perawat dalam durasi kerja $>8$ jam hanya 6 perawat yang memiliki tingkat kelelahan dengan kategori rendah $(40,0 \%)$. Sedangkan perawat yang tingkat kelelahan dengan kategori sedang berjumlah 9 perawat dengan nilai $(60,0 \%)$. Dan sebanyak 23 perawat yang mengalami tingkat kelelahan dengan kategori rendah dengan nilai $(71,9 \%)$ yang bekerja $\leq 8$ jam serta 9 perawat $(28,1 \%)$ dengan tingkat kelelahan sedang.

Tabel 8. Hubungan Perawat Berdasarkan Durasi Kerja Dengan Tingkat Kelelahan

\begin{tabular}{cccc}
\hline $\begin{array}{c}\text { Durasi } \\
\text { Kerja }\end{array}$ & \multicolumn{2}{c}{ Tingkat Kelelahan } & \\
\cline { 2 - 3 } & $\begin{array}{c}\text { Rendah } \\
(\%)\end{array}$ & $\begin{array}{c}\text { Sedang } \\
(\%)\end{array}$ & Jumlah \\
\hline > 8 Jam & $\begin{array}{c}6 \\
(40 \%)\end{array}$ & $\begin{array}{c}9 \\
(60 \%)\end{array}$ & $\begin{array}{c}15 \\
(100 \%)\end{array}$ \\
\hline 8 Jam & $\begin{array}{c}23 \\
(71,9 \%)\end{array}$ & $\begin{array}{c}(28,1 \%) \\
(100 \%)\end{array}$ \\
\hline Jumlah & 29 & 18 & 47 \\
\hline$\rho=0,076$ & & & \\
Hasil & uji & statistik & chi-square
\end{tabular}

menunjukkan bahwa nilai $\rho=0,076$ $(\rho>0,05)$, artinya $\mathrm{H}_{0}$ gagal ditolak atau tidak ada hubungan yang signifikan antara durasi kerja dengan tingkat kelelahan. Lamanya seseorang bekerja atau kehidupan dalam keluarga dan masyarakat. Memperpanjang waktu kerja lebih dari itu biasanya diserta menurunnya efisiensi, timbulnya kelelahan, penyakit dan kecelakaan (Suma'mur, 2010).

Pada table 9. dari 47 perawat, didapat sebanyak 13 perawat waktu istirahat kurang dengan tingkat kelelahan dengan kategori rendah $(86,7 \%)$ dan 2 perawat yang mengalami tingkat kelelahan sedang $(13,3 \%)$. Sedangkan perawat yang cukup dalam waktu istirahat sebanyak 16 perawat $(50,0 \%)$ dengan tingkat kelelahan rendah dan 16 perawat yang mengalami tingkat kelelahan sedang $(50,0 \%)$.

Tabel 9. Hubungan Waktu Istirahat dengan Tingkat Kelelahan

\begin{tabular}{cccc}
\hline \multirow{2}{*}{$\begin{array}{c}\text { Waktu } \\
\text { Istirahat }\end{array}$} & \multicolumn{2}{c}{ Tingkat Kelelahan } & \\
\cline { 2 - 3 } & $\begin{array}{c}\text { Rendah } \\
(\%)\end{array}$ & $\begin{array}{c}\text { Sedang } \\
(\%)\end{array}$ & Jumlah \\
\hline \multirow{2}{*}{ Kurang } & $\begin{array}{c}13 \\
(86,7)\end{array}$ & $\begin{array}{c}2 \\
(13,3)\end{array}$ & $\begin{array}{c}15 \\
(100)\end{array}$ \\
\hline \multirow{2}{*}{ Cukup } & 16 & 16 & 32 \\
& $(50)$ & $(50)$ & $(100)$ \\
\hline Jumlah & 29 & 18 & 47 \\
\hline$\rho=0,037$ & & &
\end{tabular}

Hasil uji statistik chi-square menunjukkan bahwa nilai $\rho=0,037 \quad(\rho<$ $0,05)$, artinya $\mathrm{H}_{0}$ ditolak, maka ada hubungan yang signifikan antara waktu istirahat dengan tingkat kelelahan. Dari 47 perawat ternyata hanya 13 perawat yang kurang istirahat meskipun tidak terlalu besar, namun keadaan seperti itu tidak dapat dilakukan secara terus menerus, melainkan perlu disertai istirahat yang memberi kesempatan kepada tubuh untuk melakukan pemulihan kembali.

Pada table 10. terdapat 6 perawat yang ada di shift malam dengan tingkat kelelahan rendah $(46,2 \%)$ dan 7 perawat dengan tingkat kelelahan sedang $(53,8 \%)$. Yang bekerja di shift pagi berjumlah 12 perawat dengan tingkat kelelahan rendah $75,0 \%$ dan 4 perawat dengan tingkat kelelahan sedang $(25,0 \%)$. Yang bekerja di shift sore 11 perawat dengan tingkat kelelahan rendah $(61,1 \%)$ dan 7 perawat dengan tingkat kelelahan sedang $(38,9 \%)$. Hasil uji statistik chi-square menunjukkan 
bahwa nilai $\rho=0,282(\rho>0,05)$, artinya $\mathrm{H}_{0}$ gagal ditolak atau tidak ada hubungan yang signifikan antara shift kerja dengan tingkat kelelahan.

Tabel 10. Hubungan Shift Kerja dengan
Tingkat Kelelahan Perawat

\begin{tabular}{cccc}
\hline \multirow{2}{*}{ Shift Kerja } & \multicolumn{3}{c}{ Tingkat Kelelahan } \\
\cline { 2 - 3 } & $\begin{array}{c}\text { Rendah } \\
(\%)\end{array}$ & $\begin{array}{c}\text { Sedang } \\
(\%)\end{array}$ & Jumlah \\
\hline Shift Malam & $\begin{array}{c}6 \\
(46)\end{array}$ & $\begin{array}{c}7 \\
(53,8)\end{array}$ & $\begin{array}{c}13 \\
(100)\end{array}$ \\
\hline Shift Pagi & $\begin{array}{c}12 \\
(75)\end{array}$ & $\begin{array}{c}4 \\
(25)\end{array}$ & $\begin{array}{c}16 \\
(100)\end{array}$ \\
\hline Shift Sore & $\begin{array}{c}7 \\
(61,1)\end{array}$ & $\begin{array}{c}7 \\
(38,9)\end{array}$ & $\begin{array}{c}18 \\
(100)\end{array}$ \\
\hline Jumlah & 29 & 18 & 47 \\
\hline$\rho=0,282$ & & &
\end{tabular}

Tidak ada hubungan antara shift kerja dengan tingkat kelelahan bisa saja terjadi karena menurut Pheasant (1997) dalam Martina (2015), menyatakan bahwa para pekerja di sektor industri pada negara berkembang menggunakan shift kerja yang terjadwal baik secara tetap maupun tidak tetap ataupun diluar jam-jam normal dalam bekerja. Dari sistem tersebut dapat menimbulkan akibat pada kehidupan sosial dan kenyaman yang seimbang dalam pekerjaan, sehingga dapat meminimalisir hal terjadinya kelelahan yang cukup tinggi terhadap perawat.

Pada tabel 11, perawat dengan kriteria usia 20-30 tahun berjumlah 20 orang mengalami tingkat kelelahan rendah $(64,5 \%)$ dan 11 perawat mengalami tingkat kelelahan sedang $(35,5 \%)$. Sedangkan usia $>30$ tahun yang mengalami tingkat kelelahan rendah berjumlah 9 perawat dengan nilai $(56,3 \%)$, dan 7 perawat dengan tingkat kelelahan sedang (43,8\%). Hasil uji statistik chi-square menunjukkan bahwa nilai $\rho=0,0814(\rho>0,05)$, berarti $\mathrm{H}_{0}$ gagal ditolak atau tidak ada hubungan yang signifikan antara usia dengan tingkat kelelahan.
Tabel 11. Hubungan Usia Perawat dengan Tingkat Kelelahan

\begin{tabular}{cccc}
\hline \multirow{2}{*}{$\begin{array}{c}\text { Usia } \\
\text { Perawat }\end{array}$} & \multicolumn{3}{l}{ Tingkat Kelelahan } \\
\cline { 2 - 4 } & $\begin{array}{c}\text { Rendah } \\
(\%)\end{array}$ & $\begin{array}{c}\text { Sedang } \\
(\%)\end{array}$ & Jumlah \\
\hline 20-30 tahun & $\begin{array}{c}20 \\
(64)\end{array}$ & $\begin{array}{c}11 \\
(35,5)\end{array}$ & $\begin{array}{c}31 \\
(100)\end{array}$ \\
\hline$>30$ tahun & $\begin{array}{c}9 \\
(56)\end{array}$ & $\begin{array}{c}7 \\
(43,8)\end{array}$ & $\begin{array}{c}16 \\
(100)\end{array}$ \\
\hline Jumlah & 29 & 18 & 47 \\
\hline$\rho=0,814$ & & &
\end{tabular}

Tidak ada hubungan antara usia dengan tingkat kelelahan bisa saja terjadi karena menurut (Sugijanto, 1999) menyatakan bahwa, diketahui bahwa usia $\geq$ 40 tahun memiliki tingkat stres yang tinggi sebesar $55,2 \%$ dibandingkan dengan usia $\leq$ 40 tahun yang hanya $46,6 \%$, namun berdasarkan uji statistik tidak diketahui adanya hubungan yang bermakna antara usia dengan stres kerja. Nitisemito (2000) menyatakan bahwa pegawai yang lebih muda cenderung mempunyai fisik yang kuat, sehingga diharapkan dapat bekerja keras danpada umumnya mereka belum berkeluarga atau bila sudah berkeluarga anaknya relative masih sedikit.

Pada tabel 12, perawat dengan masa kerja $\leq 5$ tahun tahun mengalami tingkat kelelahan rendah 11 perawat $(64,7 \%)$ dan yang mengalami tingkat kelelahan sedang 6 perawat $(35,3 \%)$. Sedangkan masa kerja $>5$ tahun dengan tingkat kelelahan rendah 18 perawat $(60,0 \%)$, dan yang mengalami tingkat kelelahan sedang 12 perawat $(40,0 \%)$. Hasil uji statistik chi-square menunjukkan bahwa nilai $\rho=0,995$ ( $\rho$ > $0,05)$, berarti $\mathrm{H}_{0}$ gagal ditolak, maka tidak ada hubungan yang signifikan antara masa kerja dengan tingkat kelelahan.

Pada table 12, perawat yang mengalami waktu tidur $\leq 8$ jam sebanyak 3 perawat dengan tingkat kelelahan rendah $(100 \%)$. Sedangkan jumlah perawat dengan waktu tidur > 8 jam yang mengalami tingkat kelelahan rendah sebanyak 26 perawat dengan nilai $(59,1 \%)$, dan 18 perawat yang mengalami tingkat kelelahan sedang $(40,9 \%)$. 
Tabel 12. Hubungan Masa Kerja Dengan Tingkat Kelelahan

\begin{tabular}{cccc}
\hline \multirow{2}{*}{ Masa Kerja } & \multicolumn{3}{c}{ Tingkat Kelelahan } \\
\cline { 2 - 3 } & $\begin{array}{c}\text { Rendah } \\
(\%)\end{array}$ & $\begin{array}{c}\text { Sedang } \\
(\%)\end{array}$ & Jumlah \\
\hline$\leq 5$ tahun & $\begin{array}{c}11 \\
(64,7)\end{array}$ & $\begin{array}{c}6 \\
(35,5)\end{array}$ & $\begin{array}{c}17 \\
(100)\end{array}$ \\
\hline$>5$ tahun & 18 & 12 & 30 \\
& $(60)$ & $(40)$ & $(100)$ \\
\hline Jumlah & 29 & 18 & 47 \\
\hline$\rho=0,995$ & & &
\end{tabular}

Menurut Rohmert dan Helbig, (1998) dalam Martina, (2015) tidak ada hubungan antara masa kerja dengan tingkat kelelahan bisa saja terjadi karena semakin lama periode seseorang bekerja maka akan semakin banyak tekanan yang diterima yang lama kelamaan akan menjadi tekanan konstans yang mempengaruhi proses adaptasi seseorang secara fisik dan mental.

Tabel 13. Hubungan Waktu Tidur dengan Tingkat Kelelahan

\begin{tabular}{cccc}
\hline \multirow{2}{*}{ Waktu Tidur } & \multicolumn{3}{c}{ Tingkat Kelelahan } \\
\cline { 2 - 3 } & $\begin{array}{c}\text { Rendah } \\
(\%)\end{array}$ & $\begin{array}{c}\text { Sedang } \\
(\%)\end{array}$ & Jumlah \\
\hline$\leq 8$ jam & $\begin{array}{c}3 \\
(100)\end{array}$ & 0 & $\begin{array}{c}3 \\
(100)\end{array}$ \\
\hline$>8$ jam & 26 & 18 & 44 \\
& $(59,1)$ & $(40,9)$ & $(100)$ \\
\hline Jumlah & 29 & 18 & 47 \\
\hline$\rho=0,276$ & & &
\end{tabular}

Hasil uji statistik chi square menunjukkan bahwa nilai $\rho=0,276(\rho>$ $0,05)$, berarti $\mathrm{H}_{0}$ gagal ditolak atau tidak ada hubungan yang signifikan antara waktu tidur dengan tingkat kelelahan. Tidak ada hubungan antara waktu tidur dengan tingkat kelelahan bisa saja terjadi karena semakin tinggi lama tidur, maka semakin rendah kelelahan kerja yang terjadi (Setyawati, 2014).

\section{KESIMPULAN DAN SARAN}

Faktor eksternal (durasi kerja, shift kerja) dan faktor internal (usia, jenis kelamin, masa kerja dan waktu tidur) tidak ada hubungan secara signifikan dengan tingkat kelelahan. Faktor yang memiliki hubungan dengan tingkat kelelahan hanya dari faktor eksternal (waktu istirahat). Disarankan perlu dilakukan penelitian lebih lanjut untuk mengetahui dampak dari kelelahan kerja terhadap produktivitas kerja sehingga dapat diketahui tingkat kelelahan kerja yang dialami perawat berdampak positif atau negatif bagi kinerja perawat di rumah sakit. Rumah sakit sebaiknya mempertahankan faktor eksternal dan internal yang sudah baik.

\section{DAFTAR PUSTAKA}

Suma'mur, (2010). Ergonomi Untuk Produktivitas Kerja, Jakarta : CV Haji Masaagung.

Jason-boone, (2015, Februari Kamis). Aturan jadwal kerja perawat. Retneved April Selasa, 2017 from Docslide : http://dokumen.tipsw/dokuments/aturan -jadwal-kerja-perawat.html.

Keep, A.A., (2014). Indeks massa tubuh menurut who dan asia pasifik. Retrieved April Selasa, 2017, from perwatan kesehatan: http://perawatan kesehatan.com

Kusumawardani, L., (2012). Pengaruh shif kerja terhadap kelelahan kerja perawat wanita bagian rawat inap di rumah sakit Dr. Oen Surakarta. Surakarta: Universitas Sebelas Maret.

Martina, G., (2015). Faktor-faktor yang mempengaruhi tingkat kelelahan pada pengemudi stransjakarta koridor 9 tahun 2015. Jakarta: Politeknik Kesehatan Kementerian Kesehatan Jakarta 2.

Ritongga, N.I., (2016). Faktor-faktor yang mempengaruhi kelelahan kerja perawat baru lulusan psik uin jakarta. Jakarta: Uin.

Sari, D.A., (2016). Faktor-faktor yang berhubungan dengan strs kerja pada perawat ICU (Intensive Care Unit) di rumah saki umum pusat fatmawati tahun 2016 Jakarta: Politeknik Kesehatan Kementerian Kesehatan Jakarta 2. 